\title{
Talking about the Characteristics and Developing Status of Pop Singing
}

\author{
Hailan Ren \\ Anshan Normal University \\ Anshan, China
}

\begin{abstract}
With the continuous development of social and cultural life, Pop music, a symbol of the social fashion vane, has become an important part of people's cultural life. It has also received more attention and research as a social and cultural phenomenon in the world. Popular singing is unique in its modern fashion and the performance style that is close to people's life, and be loved by people. This article is a brief description of its artistic features and the current situation of the development of popular singing in China and foreign countries.
\end{abstract}

Keywords—Pop singing; characteristic; developmental status

\section{INTRODUCTION}

Nowadays, Pop music has become a part of people's cultural life. The great influence is obvious to all. It is popular with the characteristics of popularity, fashion and personalization. Especially popular songs widely favored because of its simple and natural singing style, especially by the younger generation. There are popular singers on the screen and all kinds of music on the Internet. Pop music has penetrated into the lives of people. Popular singing is a combination of music, form, dance, and performance as a whole. Because of its modern fashion, it is close to the performance style of people's life, it made pop singing more entertaining and commercial than other styles of singing. So it's loved by the masses, especially young people. But it does not mean that pop singing is lack of professionalism and artistry. With the increase in the difficulty of the work and skill .It also embodies a strong professional and artistic nature.

\section{The ARTISTIC FEATURES OF PoP SingING}

\section{A. Mass Communication}

Because the content and form of pop songs are close to people's life and realest emotions, so the most important feature of pop singing is the use of the most natural and authentic timbre. A lot of people who have not been trained in professional vocal music can also express the content of the songs and their feelings with their real and simple way of singing. No matter how the song is, a lot of people can get in touch with pop singing, however, the Bel canto and national singing can't be sung without professional training. So the popularity of popular singing is much higher, and it is also learned by more people. The popular characteristic of popular singing is the one that other singing methods are not available.

\section{B. A Stylish Way of Performance}

The most important thing in popular singing is individualization. The singer's singing is the most taboo, without its own characteristics. Be sure to highlight the personalized voice and performance. So there are a lot of popular singing voice unique skills, such as: gas, falsetto sound, mute, shouting, singing coloratura etc.. The performance emphasis the pure and natural style, it can be very free improvisation, complete with their own feelings to sing, do not need too many constraints, there is a unique flavor of natural carving. At the same time, the performance of singer's language, dance, fashion and electronic technology is also very fashionable. It is very popular among young people. It represents the current fashion trend and leads the trend of the society.

\section{Pluralistic Musical Elements}

Popular singing styles include jazz, rock, music and dance, Latin, rap and so on. There are various forms of orchestration, including orchestral music, electric vocal music, folk music, and their combination, including a variety of musical elements. For example, The song "Beijing night" includes Peking opera, elements of ancient poetry rhythm and rock with rhythm and style of singing, accompaniment of musical instruments have also had national musical instruments, electro acoustic musical instruments, including computer produced music, combined with music containing numerous elements. It can be said that any other singing method can't contain such a rich musical element. A variety of musical elements are the unique artistic features of popular singing.

\section{The CurRent Situation of the DeVElopment of POPULAR SINGING IN CHINA AND FOREIGN COUNTRIES}

\section{A. The Current Situation of the Development of Popular Singing in Europe and America}

Europe and America are the birthplace of pop music. Pop music has emerged since the end of the nineteenth Century. It has been 100 years old. The popular music in Europe and America is mainly based on the black American music, the development of the traditional music and folk music of other 
countries in Europe. The pop singing in twentieth Century has been developing rapidly in Europe and America. They began to study the pop singing theory and practice in a early time and made it develop and perfect. European and American pop vocal types and styles include jazz, Bruce, spirituals, rock, country, Latin, hip-hop, Saul etc. They all have their own rhythm features such as singing, syncopated rhythm from jazz, rhythm strong from rock music, natural and fresh country music, passionate Latin melodies and Saul's coloratura. European and American pop vocal mainly through passionate and improvised performance to reflect the content of the works, the singing skill is very difficult, such as: high cadenza virtuoso, true sound conversion, continuous over eight degrees. Without skillful singing, it is unable to be completed. It has enhanced the appeal of the works and has produced great artistic charm. Nowadays, the pop music singing in Europe and America has reached a very high level. At the same time, they have formed a series of communicational patterns and business operational modes for the commercial characteristics of pop singing, which further promoted the development of pop singing. Once Whitney Houston sang a song called "I will always love you" and then swept the world, and for the first time, Chinese people felt the artistic charm of the pop singing in Europe and America. The performance of Adele and Justin Bibber attracted many young people's sight, becoming a pop singer has become the dream of many young people. The annual session of the American Grammy popular music festival is also attracting 170 countries around the world and about 1 billion 700 million of the audience's attention, along with the development of modern network technology, television and other media, European and American pop singing has more attention, it leads the world's trend and direction.

\section{B. The Current Development of Popular Singing in China}

The development of China's popular music has experienced a hard long process of exploration in the creation, singing and so on, because it has its own unique development, restricted by the political, economic, cultural and other factors, the development environment and developmental speed is far behind Europe and the United states. In fact, Chinese pop songs have appeared early in the early $20 \mathrm{~s}$ and $30 \mathrm{~s}$. At that time, most of the popular songs adopted the melody tone of our folk tune, and at the same time, it borrowed from the rhythm of American jazz and dance. It can be said that the fusion of Chinese and western music is the first step. At that time the most representative composer is Jinhui Li, the representative of "drizzling", "sister, I love you", was the representative with singer, her masterpiece "wandering songstress" spread so far. But in a period of time after the foundation of the country, popular songs in China was once considered "demoralizing tune", the development has been greatly restricted. Until the beginning of 80 s, with the pace of reforming and opening up, China's popular singing was gradually developed, 1986 The concert "let the world is full of love" launched, "popular singing" established for the first time in the national youth singer Grand Prix, marks the mainland pop music creation and singing music has become an important part of social life.
Then a strong "northwest wind" is blowing up in the mainland, shouting and singing become a prominent singing method, representing the attempt of Chinese pop singing to embody distinctive national characteristics. In 90s, with the influx of pop music in Hong Kong, Taiwan, Europe and America, it is a trend to study their advanced singing methods, creative techniques, the operation methods of the commercial packaging of singers by imitation and learning. In recent years, with the rapid development of Internet, electronics and other high-tech, international cultural exchanges are also more frequent. In such a big environment, China's pop music has been developing rapidly both in creation and singing. It has also greatly improved the understanding of the commercial attributes of pop music and the corresponding operation procedures. Some pop singers have pop world attention, such as Dingding Sa get awards on behalf of the world's highest level of popular music event "Grammy" music singing contest awards for the first time; "Super Girls" winner Jane Zhang debut in the United States "Super Idol" program, her singing has received great recognition and audience. Our music is gradually from simple imitation, creation of popular music "China wind" features, the Chinese opera, ancient poetry, folk music and other elements well into popular singing and songwriting, like "chrysanthemum Taiwan", "Beijing night", "blue and white" is the representative of works by the public praise and love. It can be said that at present, the pop singing in China has been gradually maturing from the initial imitation to the maturity in many years of singing practice, and has formed the singing style and method with Chinese characteristics, and is gradually integrating with the international practice. As a part of Chinese music culture, it has promoted the vigorous development of Chinese vocal music with the beauty of beauty and the nation.

\section{CONCLUSION}

It can be said that the current domestic and foreign pop music not only has developed to a very high level, but also their artistic and commercial characteristics of popular music form a series of creative methods, methods, forms of communication and business operations, so as to better promote the development of popular music and influence.

\section{REFERENCES}

[1] Hongjian Wang. An introduction to art [M]. Guangzhou: culture and Art publishing house 2000

[2] Naixian Pan vocal road [M]. Shanghai: Shanghai music publishing house, 2003

[3] Naixian Pan Modern popular songs singing quest [M]. Shanghai: Shanghai music publishing house, 2004

[4] Xiaofeng Wang et al. The European and American popular music guide [M]. Xi'an: World Book Inc, 2000

[5] Xiaogang Xiang. Pop music -- twentieth Century Chinese music history to perfect the construction project [J]. music art, 2003 